\title{
HABITAT USE OF THE CRAYFISH AUSTROPOTAMOBIUS TORRENTIUM IN SMALL BROOKS AND IN LAKE CONSTANCE, SOUTHERN GERMANY.
}

\author{
M. RENZ and T. BREITHAUPT
}

Lehrstuhl Zoology and Evolutionary Biology, Department of Biology, University of Konstanz, Postfach 5560, D-78457 Konstanz, Germany.

\section{ABSTRACT}

Habitat use of Austropotamobius torrentium was studied in two small brook systems winding through woods and open grassland and in Lake Constance at the outflow of the river Rhine. Flow velocities in the brooks ranged from less than $1 \mathrm{~cm} / \mathrm{s}$ to $66 \mathrm{~cm} / \mathrm{s}$ and resulted in average flow discharges between $1.8 \mathrm{l} / \mathrm{s}$ and $27.4 \mathrm{l} / \mathrm{s}$. Flow velocities in the Rhine were between 30 and $62 \mathrm{~cm} / \mathrm{s}$. All 5 sites inhabited by crayfish had a slightly basic $\mathrm{pH}$, high $\mathrm{Ca}^{2+}$-concentrations and a Saprobial index of about 2 indicating moderate pollution. Two brook stretches were not occupied by crayfish. In one case an eutrophic lake influenced the downstream brook stretch causing an increase in the Saprobial index to 2.5. Further downstream a pipe inhibited the upstream-invasion of crayfish. The second stretch was an artificial and monotonous channel with high flow velocities.

Food selection experiments with submersed flora and fauna collected in the habitat showed that the stone craytish fed on macroinvertebrates as well as on small fish, submersed macrophytes and dead leaves. At low temperatures $\left(7^{\circ} \mathrm{C}\right)$ their food was dominated by plants while at higher temperatures $\left(14^{\circ} \mathrm{C}\right)$ they consumed more macroinvertebrates than plants. It is concluded that stone crayfish inhabit a variety of running waters and that a main threat to this species is channelling and obstructions of flow ways.

Key-words : freshwater crayfish, Austropotamobius torrentium, habitat structure, water quality, food preference, brook obstruction.

\section{L'UTILISATION DE L'HABITAT DE L'ÉCREVISSE AUSTROPOTAMOBIUS TORRENTIUM DANS DES PETITS RUISSEAUX ET DANS LE LAC DE CONSTANCE AU SUD DE L'ALLEMAGNE.}

\section{RÉSUMÉ}

L'utilisation de l'habitat d'Austropotamobius torrentium a été étudiée dans deux petits systèmes de ruisseaux qui serpentent à travers des forêts, des prés et dans le Lac de Constance où le Rhin quitte le lac. Les vélocités du courant dans les ruisseaux se situaient entre moins d'1 cm/s et $66 \mathrm{~cm} / \mathrm{s}$ et l'écoulement de volumes d'eau en moyenne 
entre $1,8 \mathrm{l} / \mathrm{s}$ et $27,4 \mathrm{l} / \mathrm{s}$. Les vélocités du courant mesurées dans le Rhin étaient de 30 à $62 \mathrm{~cm} / \mathrm{s}$. Tous les emplacements habités par les écrevisses avaient un $\mathrm{pH}$ légèrement supérieur à 7 , des concentrations élevées de $\mathrm{Ca}^{2+}$ et un index saprobial de 2 (qualité biologique de l'eau). Deux parties des ruisseaux étaient vides d'écrevisses. Dans un cas, un lac eutrophisé influençait la partie aval du ruisseau et avait causé une augmentation de l'index saprobial à 2,5. Plus en aval du ruisseau un tuyau empêchait le passage des écrevisses de la partie du ruisseau en aval. La deuxième partie du ruisseau était un cours d'eau artificiel et monotone avec des vélocités de courant élevées.

Des expériences sur la sélection de la nourriture faites avec la flore et la faune submergées qui avaient été rassemblées dans l'habitat, ont montré que les écrevisses se nourrissaient de macro-invertébrés, de petits poissons, de " macrophytes " ainsi que de feuilles mortes submergées. A de basses températures $\left(7^{\circ} \mathrm{C}\right)$ elles se nourrissaient surtout des plantes tandis qu'à des températures plus élevées $\left(14^{\circ} \mathrm{C}\right)$ elles consommaient plutôt des macro-invertebrés. Finalement on peut résumer que les écrevisses occupent des cours d'eau divers et que la menace principale pour cette espèce est la canalisation et les obstructions des ruisseaux.

Mots-clés : écrevisses, Austropotamobius torrentium, structure de l'habitat, qualité de l'eau, sélection de la nourriture, obstruction des ruisseaux.

\section{INTRODUCTION}

Austropotamobius torrentium is the smallest of the European crayfish species. It never was of great economic interest and was never stocked (TROSCHEL and DEHUS, 1993). The geographic distribution ranges from Southern Germany southeastward to the Balkan peninsula (Figure 1 ; LAURENT, 1988). The higher regions close to the Rhine near Cologne and the northern tributaries of the river Main form the upper boundary (Figure 1). Tributaries of the river Moselle in France and in Luxembourg constitute the western boundary of its distribution (ATTEN, 1988 ; MACHINO, 1996). In contrast to the other species native to Germany it still inhabits many. waters in Southern Germany (DEHUS, 1997). A. torrentium occupies many small brooks along the Danube catchment with the iron door (Romania) as the eastern boundary. and the Vardar system in Yugoslavian Macedonia as the southern boundary (Figure 1). Few studies have focused on the habitat demands of this species. The name $A$. torrentium suggests a turbulent flow habitat. HOGGER (1988) reports a preference for cold, fast-flowing upland streams and a limitation of the distribution. to alpine regions. LAURENT (1988) in contrast emphasizes a habitat in very small.brooks with rocky substrates, as the German name "Steinkrebs " suggests. He refers to occurrences on the Swiss plateau, where they are found at lower altitudes than Austropotamobius pallipes, to occurrences in the Danube basin in Bavaria and to mountain springs and brooks in Yugoslavia. where they are found at higher altitudes than in more northern countries. BOHL (1989a, b, 1999) characterizes the Bavarian crayfish stocks as being restricted to remote upstream areas in the low mountain ranges within an altitude range of $200 \mathrm{~m}$ to $800 \mathrm{~m}$ above sea-level. In Bavaria, stone crayfish are exclusively found in small brooks (BOHL, 1999). Like the other European crayfish the stone crayfish is susceptible to the craytish plague, a fungus introduced to Europe with the introduction of foreign crayfish. However, stone crayfish populations do not suffer much from the crayfish plague since their habitats usually do not overlap with that of alien crayfish carrying the fungus (DEHUS, 1997). Furthermore, brook obstructions may protect stone crayfish populations from an invasion of alien species. On the other hand these obstructions can constitute a threat for Austropotamobius torrentium by isolating local populations. 
In this paper we examine five stone crayfish habitats in Southern Germany. Four sites are located in small brooks near Constance and one site is in Lake Constance. In addition, food-selection experiments aim to reveal preferences in the diet of this species.

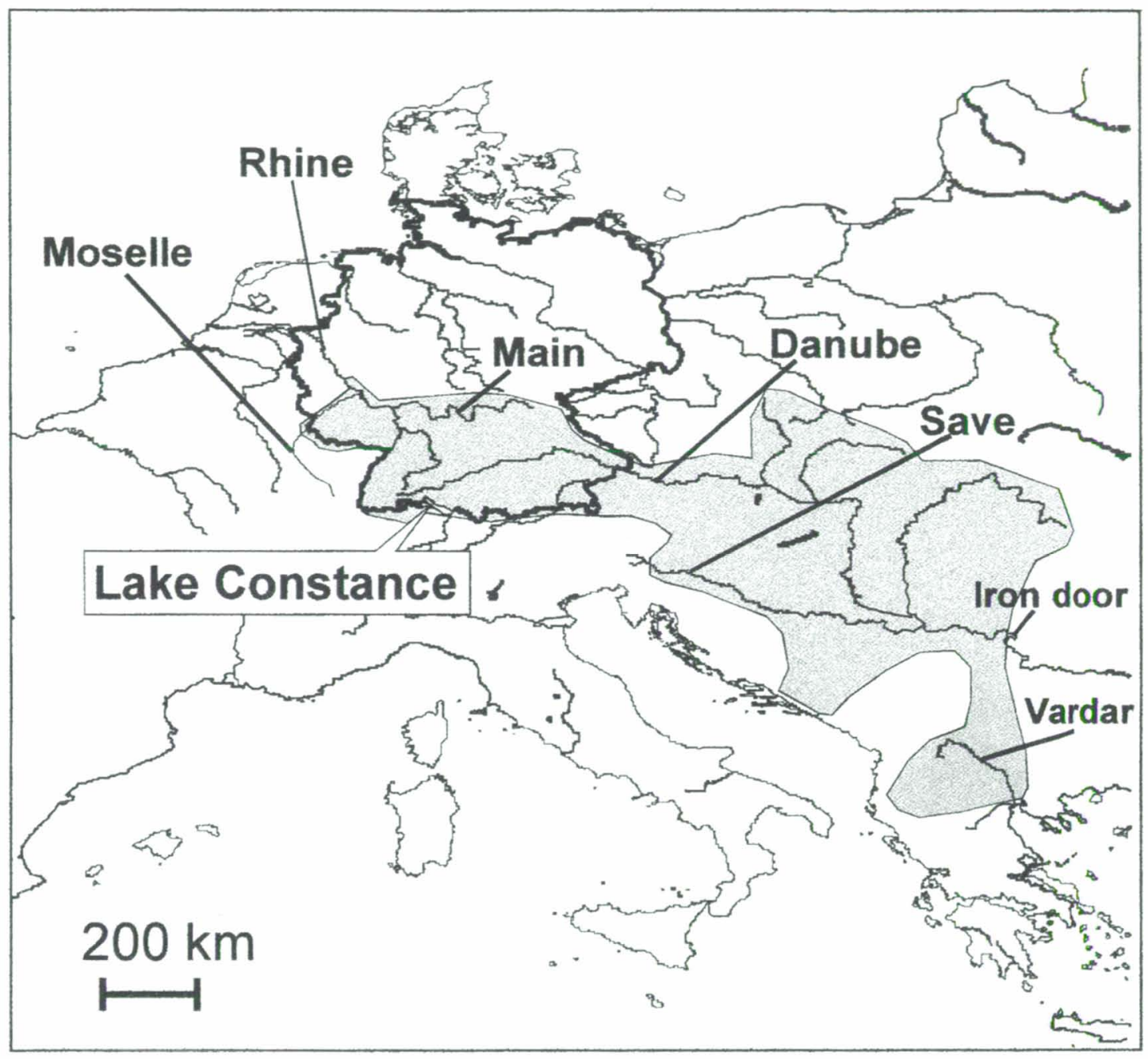

Figure 1

Distribution of Austropotamobius torrentium in Germany (national border is marked) and Europe (LAURENT, 1988 ; ATTEN, 1988 ; TROSCHEL and DEHUS, 1993 ; MACHINO, 1996 ; BOHL, 1999).

\section{Figure 1}

Distribution d'Austropotamobius torrentium en Allemagne (la frontière nationale est marquée) et en Europe (LAURENT, 1988 ; ATTEN, 1988 ; TROSĆHEL et DEHUS, 1993 ; MACHINO, 1996 ; BOHL, 1999).

\section{MATERIAL AND METHODS}

All five study sites were near Lake Constance (Figure 2) at altitudes ranging between $400 \mathrm{~m}$ above sea-level (Lake Constance) and 450-500 m (brooks). Site 1 was a narrow and shallow forest brook. Sites 2,3 and 4 were located at a second brook system. Site 5 was in Lake Constance at the outflow of the river Rhine. 
The potential shelter area ( \% coverage »; Table I) was established after drawing maps (1:20) from the brook study sites including stones and wood greater than $10 \mathrm{~cm}$. The maps were scanned into a MACINTOSH computer and the areas covered by such substrate were calculated using the software NIH Image 1.6. (written by Wayne Rasband at the US National Institute of Health ; www-site : http://rsb.info.nih.gov/nihimage/Default.html).

Conductivity, $\mathrm{pH}$, temperature and oxygen were measured using electronic equipment (conductivity meter : GLM 200 A, pH-temperature-meter : GPRT 1400A, VDSF-Umwelttechnik ; oxygen-meter : HI 9142, HANNA-Instruments). Ca ${ }^{2+}$-concentration was measured according to DIN 38406-E3-2 (NORMENAUSSCHUB WASSERWESEN (NAW) im DIN (Deutsches institut für Normung) e.V., 1987). The flow velocity was measured in $5 \mathrm{~cm}$ intervals across the brook at $40 \%$ water depth using a blade anemometer (type $\mu \mathrm{P}-\mathrm{TAD}$, Höntsch Instruments) and water discharge was calculated (DYCK and PESCHKE, 1989). Measurements were taken monthly from April to December 1997.

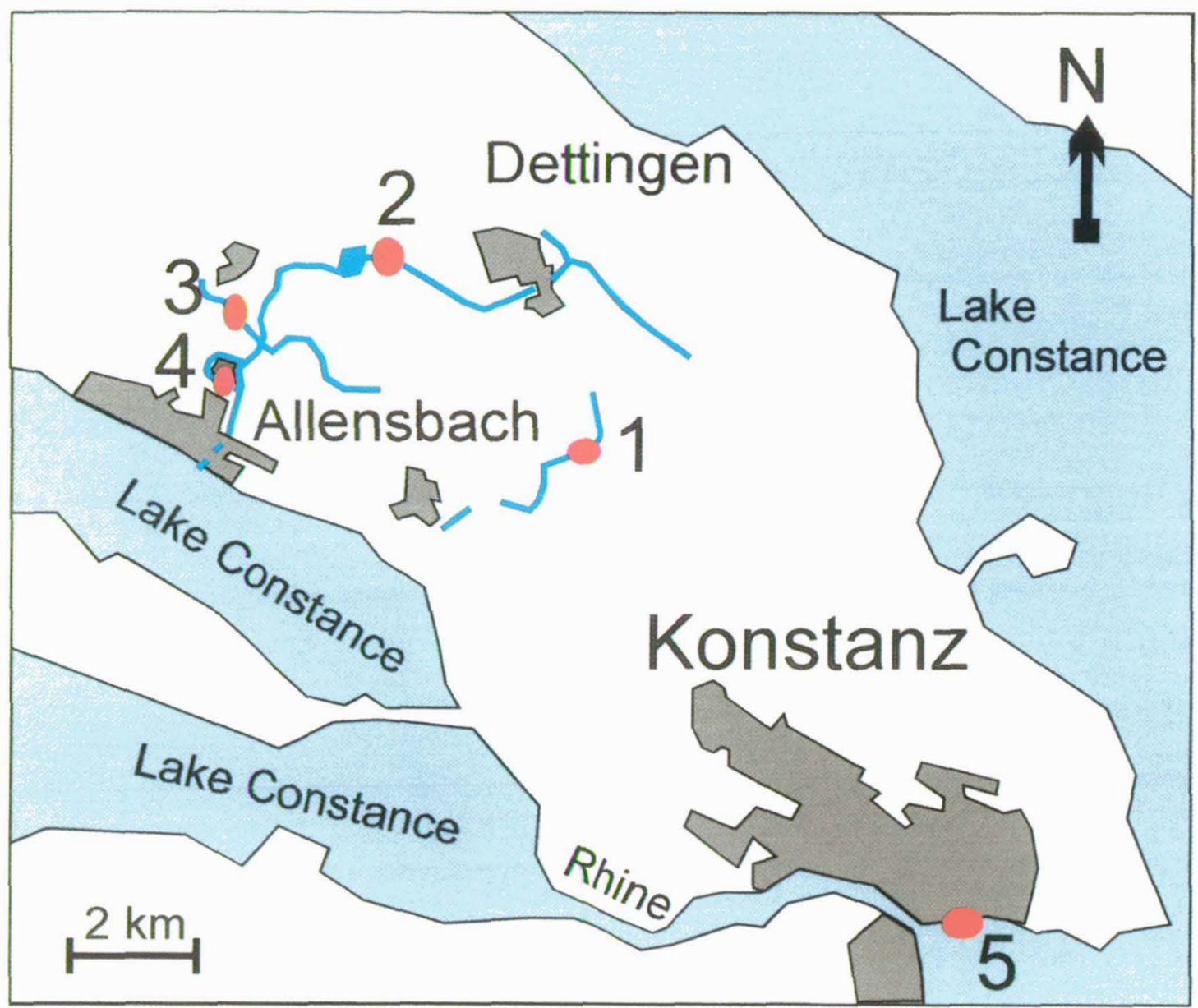

Figure 2

Map of the area investigated at Lake Constance, Germany, with location of study sites marked.

\section{Figure 2}

Carte géographique de la région étudiée au Lac de Constance, Allemagne, où les endroits étudiés sont marqués. 
Crayfish abundance in the brooks was estimated in June and July 1997 by hand-capturing, marking and recapturing individuals at night using strong flash lights. Animals were captured in weekly intervals on up to 7 nights. In brook sections where no crayfish was found craytish traps (distributed by $M$. Keller, Augsburg, Germany) were disposed as an additional control for crayfish presence. The animals were marked by gluing small numbered plastic tags on the carapace. Population size and density were calculated according to JOLLY (1965) and SEBER (1965).

$$
P_{i}=\left(\frac{s_{i} \cdot z_{i}}{R_{i}}+r_{i}\right) \cdot \frac{n}{r_{i}}
$$

$P_{i}=$ estimate of population at day $i$
$s_{i}=$ number of animals released at day $i$
$z_{i}=$ sum of animals marked before day $i$ and recaptured after day $i$
$r_{i}=$ number of recaptured marked animals at day $i$
$n_{i}=$ total number of captured animals at day $i$
$R_{i}=$ sum of animals marked and released at day $i$ and recaptured after day $i$

The biological water quality was determined according to the Saprobial system (NORMENAUSSCHUB WASSERWESEN (NAW) im DIN (Deutsches Institut für Normung) e.V., 1987 ; NAGEL, 1989). The abundance, biological value (Saprobial index of species) and indicative value of the collected macroinvertebrates give the biological water quality (Saprobial index) of the habitat. An index of 1 indicates no pollution while an index of 4 indicates strong pollution. Biological water quality was determined twice - in March and in September 1997 - by sampling the macroinvertebrates with a handnet of $20 \mathrm{~cm}$ diameter and $300 \mu \mathrm{m}$ mesh. All substrates were sampled with the same intensity for 10 minutes. Samples were conserved in $70 \%$ ethanol, identified and counted in the lab. The index was calculated using the following equation (NORMENAUSSCHUB WASSERWESEN (NAW) im DIN (Deutsches Institut für Normung) e.V., 1987) :

$$
S=\frac{\sum h_{i} \cdot g_{i} \cdot s_{i}}{\sum h_{i} \cdot g_{i}}
$$

$\mathrm{S}=$ Saprobial index

$h_{i}=$ relative frequency of species $i$

$g_{i}=$ value of indication of species $i$

$\mathrm{s}_{\mathrm{i}}=$ Saprobial index of species $i$

Since due to their high abundance not all individuals of a species could be counted completely we estimated the frequency of all species using the relative scale $\left(h_{i}\right)$ of MEYER (1987). The value of indication $g_{i}$ and the Saprobial index of the species $i, s_{i}$ were taken from DIN 38410, part 2 (NORMENAUSSCHUB WASSERWESEN (NAW) im DIN (Deutsches Institut für Normung) e.V., 1987). 
In order to determine the composition of the benthic community the biomass of all species was determined by drying the animals or plants at $105^{\circ} \mathrm{C}$ or by calculating the dry weight according to MEYER (1989). Presence of fish was documented during the nocturnal crayfish collection. In addition, fish that were caught in the crayfish traps were identified.

For the food selection experiments adult crayfish of both sex were isolated in 12 I tanks provided with a shelter and a $5 \mathrm{~mm}$ layer of sand covering the bottom. Tests were conducted in the second week of May and in the first week of June respectively at two different water temperatures to test for the influence of season on diet : 5 animals were tested at $7^{\circ} \mathrm{C}$ (May experiments) and 17 animals at $14^{\circ} \mathrm{C}$ (June experiments). At the capture sites the temperatures ranged from $6^{\circ} \mathrm{C}$ (End of April) to $14^{\circ} \mathrm{C}$ (June). Crayfish as well as plants and macroinvertebrates were collected from the field sites three to eleven days before the experiments were started. For the May experiments 4 males $(21$ to $37 \mathrm{~mm}$ carapace length " $C L ")$ and one female $(23 \mathrm{~mm} \mathrm{CL})$ were used. For the June experiments 14 males ( 19 to $43 \mathrm{~mm} \mathrm{CL}$ ) and 3 females (13 to $24 \mathrm{~mm} \mathrm{CL}$ ) were used. After a few days of acclimatisation each crayfish was fed with a known weight of plants and a known amount (number, weight) of animals respectively. In order to measure the natural weight increase of the growing plants samples of all plants species were isolated at the experimental temperatures in extra aquaria without crayfish. After three days of food exposure the remaining prey animals were counted and the dry weight of remaining animals and plants was measured. The dry weight of plant material consumed was estimated by the weight difference in dry weight corrected by the weight increase due to natural growth. The following food sources were offered:

plants : Veronica beccabunga, Callitriche spec., Apium spec., fallen leaves, and the cases of Trichoptera (family : Limnephilidae);

animals : Limnephilidae, Ephemeroptera (Baetis spec. and Paraleptophlebia spec.), Dreissena polymorpha, different Gastropoda, Gammarus fossarum.

Additionally, we tested the ability of stone crayfish to feed on flatworms (Turbellaria : Dugesia gonocephala), leeches (Hirudinea : Glossiphonia complanata, Erpobdella octoculata) and fish (Gasterosteus aculeatus) that were collected at the study sites. Flatworms and leeches were introduced to aquaria with only one crayfish. Ten small live sticklebacks (Gasterosteus aculeatus) were introduced to a tank $(1 \times 1 \times 0.15 \mathrm{~m})$ containing 8 adult crayfish.

\section{RESULTS}

\section{Habitat characteristics}

The physical and chemical characteristics of the five sites are summarized in Table I. Sites 1 and 3 were at very small brooks (Figure 2, Table I). Site 1 was a $27 \mathrm{~m}$ long section of a forest brook with mainly sandy substrate partly covered by dead wood and leaves (Table I). Site 3 was a brook running through meadows flanked by a fragmentary stripe of bushes. The substrate was muddy to sandy and only a short section contained gravel to stony substrate. Sites 2 and 4 were located on a bigger brook (Figure 2). Site 2 is located further upstream running through meadows and pasture with only a few trees and bushes nearby. It was subdivided into three different sections : the upstream section had a sandy substrate, the mid section ran in a tunnel below a street (see Figure 3) and had a stony substrate. The downstream section had a gravel substrate. Site 4 was located five kilometres downstream of site 2 . It was a $20 \mathrm{~m}$ long brook section flowing through an 
industrial area. The substrate was gravel. Site 5 was in Lake Constance at the outflow of the river Rhine (Figure 2). Here the substrate consisted of sand, gravel and bigger stones. The study site had a length of $60 \mathrm{~m}$.

\section{Table I}

Physical and chemical parameters of the 5 study sites with occurrences of Austropotamobius torrentium. Length, width and maximal water depth refer to size of investigated study site.

\section{Tableau I}

Les paramètres physiques et chimiques des 5 emplacements étudiés habités par Austropotamobius torrentium. Longueur, largeur et profondeur maximale de l'eau sont celles de l'endroit étudié.

\begin{tabular}{|c|c|c|c|c|c|}
\hline parameter / study site & 1 (brook) & 2 (brook) & 3 (brook) & 4 (brook) & 5 (lake) \\
\hline length of site [m] & 45 & 30 & 20. & 20 & 60 \\
\hline brook width [m] & $0.5-1.2$ & $1-4$ & $1.2-2$ & $1.2-1.5$ & 200 \\
\hline dominant substrate & sand & $\begin{array}{c}\text { sand, gravel, } \\
\text { stones }\end{array}$ & sand & gravel & $\begin{array}{c}\text { sand, gravel, } \\
\text { stones }\end{array}$ \\
\hline$\%$ coverage (big stones, wood) & 10 & 15 & 20 & 6 & unknöwn \\
\hline max. water depth $[\mathrm{cm}]$ & $8+/-3$ & $7+/-1$ & $12+/-3$ & $10+/-3$ & 0 to 300 \\
\hline $\max$. flow speed $[\mathrm{cm} / \mathrm{s}]$ & $15+/-5$ & $56+/-6$ & $11+/-3$ & $21+1-9$ & $50+i-10$ \\
\hline flow discharge $[\mathrm{l} / \mathrm{s}]$ & $1.8+/-1.2$ & $27.4+/-10.1$ & $4.5+/-2.6$ & $8.1+/-5.0$ & unknown \\
\hline temperature $\left[{ }^{\circ} \mathrm{C}\right]$ & $10.9+/-4.3$ & $11.6+/-4.0$ & $11.9+/-4.4$ & $13.8+/-4.9$ & $14.6+/-4.8$ \\
\hline oxygen [\%] & $81.4+1-7.2$ & $74.3+/-9.7$ & $75.0+/-5.9$ & $84.1+/-8.6$ & $101.0+/-15.3$ \\
\hline $\mathrm{Ca}^{2+}$-concentration $[\mathrm{mg} / 1]$ & $109+/-4$ & $116+/-1$ & $116+/-7$ & $106+/-4$ & $49+1-6$ \\
\hline conductivity $[\mu \mathrm{S} / \mathrm{cm}]$ & $621+/-27$ & $698+/-35$ & $668+/-46$ & $639+/-26$ & $294+/-16$ \\
\hline estimated crayfish abundance & $276+/-95$ & $223+/-57$ & $228+/-47$ & $126+/-83$ & unknown \\
\hline numb. of animals marked per night & $86+/-51$ & $66+/-8$ & $74+/-12$ & $13+/-9$ & 13 \\
\hline mean recapture rates & $39+/-23 \%$ & $37+/-10 \%$ & $51+/-14 \%$ & $29+/-16 \%$ & 0 \\
\hline number of capture nights & 6 & 7 & 5 & 6 & 2 \\
\hline population density [N/meter] & 6.1 & 7.5 & 11.4 & 6.3 & unknown \\
\hline $\mathrm{pH}$ & $8.3+/-0.2$ & $7.8+/-0.2$ & $8.1+/-0.1$ & $8.3+/-0.2$ & $8.5+/-0.1$ \\
\hline Saprobial index (March) & 1.7 & 2.0 & 1.9 & 1.9 & 2.2 \\
\hline Saprobial index (September) & 1.9 & 1.8 & 1.9 & 1.9 & 2.0 \\
\hline
\end{tabular}

Water depth at the four brook study sites ranged from $3 \mathrm{~cm}$ at site 1 to $17 \mathrm{~cm}$ at site 3 (Table 1). The average of the maximal water depth was $9.0 \mathrm{~cm} \pm 3.4 \mathrm{~cm}$. The depth at site 5 increased from 0 at the shore line to $300 \mathrm{~cm}$ at $20 \mathrm{~m}$ distance from the shore. The maximum flow velocity measured in $40 \%$ water depth at the different sites on average was $28 \mathrm{~cm} / \mathrm{s} \pm 20 \mathrm{~cm} / \mathrm{s}$ with the highest velocity of $66 \mathrm{~cm} / \mathrm{s}$ measured at site 2 . The flow velocity at $2 \mathrm{~cm}$ above ground (crayfish body height) was strongly reduced with respect to the flow velocity at $40 \%$ water depth. At $2 \mathrm{~cm}$ above ground maximum flow velocities ranged from 2 to $26 \mathrm{~cm} / \mathrm{s}$. The calculated flow discharge in the brooks ranged from $0.3 \mathrm{l} / \mathrm{s}$ at site 1 to $42.9 \mathrm{l} / \mathrm{s}$ at site 2 . The oxygen values at all test sites over the whole time of investigation were higher than $74 \%$. The temperature ranged from $3.3^{\circ} \mathrm{C}$ in December at site 1 to $21.6^{\circ} \mathrm{C}$ in September at site 5 and on average was $12.5^{\circ} \mathrm{C} \pm 4.7^{\circ} \mathrm{C}$. The rock around Constance is rich in calcium carbonate, so the concentrations of $\mathrm{Ca}^{2+}$ in the brooks on average were high $(112 \pm 6 \mathrm{mg} / \mathrm{l})$ and the $\mathrm{pH}$ was slightly basic $(8.2 \pm 0.2)$ (Table I). 
The mean conductivity in the brooks was $657 \mu \mathrm{S} / \mathrm{cm} \pm 45 \mu \mathrm{S} / \mathrm{cm}$. Lake Constance had a much lower $\mathrm{Ca}^{2+}$ concentration and the conductivity amounted to only half the values in the brooks $\left(\mathrm{Ca}^{2+}: 49 \mathrm{mg} / \mathrm{l} \pm 6 \mathrm{mg} / \mathrm{l}\right.$, conductivity : $\left.294 \mu \mathrm{S} / \mathrm{cm} \pm 16 \mu \mathrm{S} / \mathrm{cm}\right)$.

\section{Distribution and abundance of stone crayfish in the brook systems}

The distribution of stone crayfish in the brook systems was discontinuous (Figure 3). Population densities of up to 11.4 animals per brook meter were found (site 3, Table I). This site offered the greatest proportion of potential shelter area (« \% coverage ; big stones, wood "; Table I). Remarkably no crayfish was found in a brook section of about $2 \mathrm{~km}$ length between study sites 2 and 4 . At the upstream site an eutrophic pond of $27,000 \mathrm{~m}^{2}$ size and a mean depth of $2 \mathrm{~m}$ limited the distribution. Further downstream the brook was canalized into two narrow pipes to cross under a street. The pipes and the street inhibited invasion from downstream. Upstream to this obstruction for about $1 \mathrm{~km}$ the brook had similar physical and chemical properties as the other study sites and thus would have been a suitable crayfish habitat.

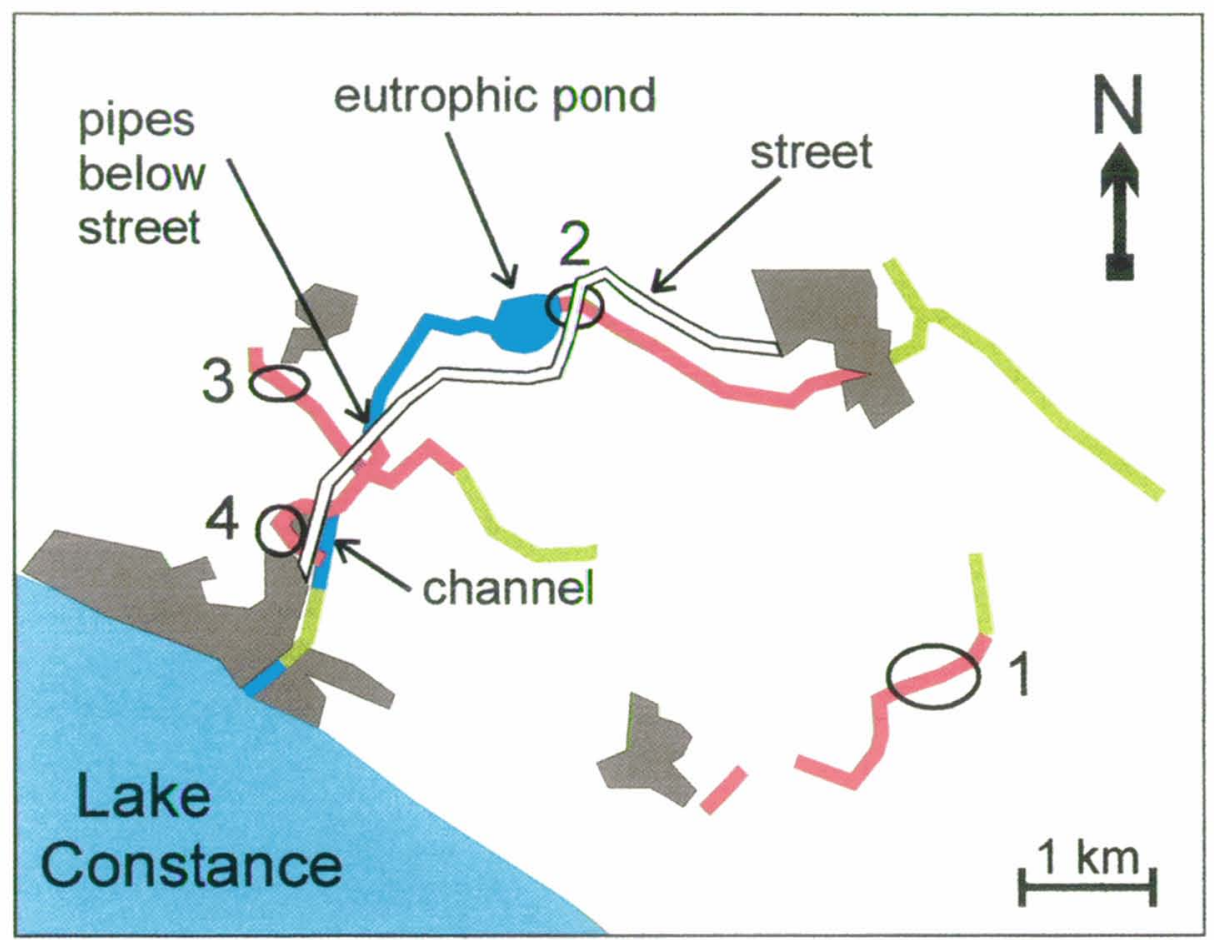

Figure 3

Distribution of Austropotamobius torrentium in the two brook systems investigated. Brook sections with crayfish occurrences are marked in red, sections with no crayfish occurrences are blue and sections that were not investigated are green. The light blue area refers to Lake Constance. Gray areas indicate villages.

\section{Figure 3}

Distribution d'Austropotamobius torrentium dans les deux systèmes de ruisseaux étudiés. Les parties du ruisseau où se trouvent des écrevisses sont marquées en rouge, les parties qui n'étaient pas habitées par les écrevisses sont marquées en bleu et les parties qui n'ont pas été étudiées sont marquées en vert. La région marquée en bleu clair correspond au Lac de Constance. Les endroits gris représentent les villages. La ligne noire indique une rue. 
A second stretch with no crayfish occurrence was a water channel leading to an old mill near study site 4 . This artificial section of the brook ran next to the street. Crayfish were only caught in the original meandering stretch of the brook but not in this water channel. Downstream to the junction of the channel and the natural stretch of the brook no crayfish was found either. While running through the village the brook was partly canalized in pipes. At the outflow of this brook to Lake Constance no crayfish was found.

\section{The macroinvertebrate community at the study sites}

The macroinvertebrate community in the four brook habitats showed seasonal changes with regard to their biomass : during spring time (Figure $4 A$ ) insect larvae (Ephemeroptera, Trichoptera and Diptera) constituted the greatest proportion of the macroinvertebrates $(45 \%)$ followed by amphipod crustaceans $(44 \%)$. In September (Figure $4 \mathrm{~B}$ ) the percentage of insect larvae was only $6 \%$ and the fauna was dominated by amphipods $(59 \%)$ and molluscs (35\%). In September, the next larval generation of insects is still very small and their biomass is low. In contrast, the biomass of Gastropoda grew during summer from, $5 \%$ to $28 \%$ of the total sampling. Similarly, the bivalves increased in abundance from spring to summer. At study site 5 (Lake Constance) Dreissena polymorpha made up more than $90 \%$ of the benthic community in spring and summer. In the section after the pond with no crayfish occurrences the proportion of Hirudinea was higher than at the other study sites (10\% as compared to maximal $1 \%$ ).

The Saprobial index ranged from 1.7 at study site 1 to 2.2 in the lake and indicates a low to moderate pollution (Table I). Small differences were found between the indices of March and September. Downstream of the eutrophic pond between study sites 2 and 3 the Saprobial index was 2.5 indicating a critical pollution.

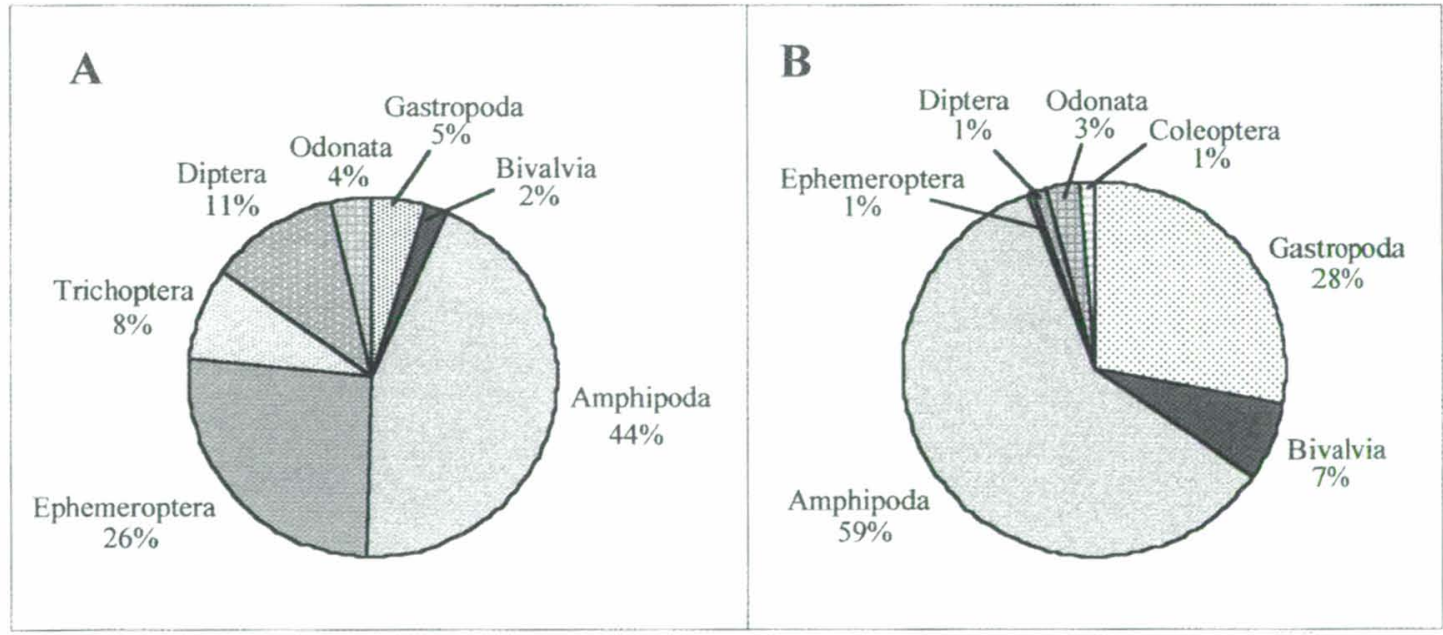

\section{Figure 4}

The biomass of the macroinvertebrate community in the four brook habitats as measured in March (A) and in September (B) 1997. Percentage data refer to the dry weight of the total sample volume. Only taxa with more than $1 \%$ of the total sample weight are considered.

\section{Figure 4}

La biomasse de la communauté des macro-invertébrés dans les quatre habitats du ruisseau mesurée en Mars (A) et en Septembre (B) 1997. Les chiffres exprimés en pourcentage se rapportent au poids sec du volume total-de l'échantillon. Seuls les taxons surpassant $1 \%$ du poids total de l'échantillon ont été pris en considération. 


\section{The fish fauna at the study sites}

With the exception of study site 1 where no fish was found we collected fish at all other study sites. Nine species were identified: Salmo trutta $f$. fario, Gasterosteus aculeatus, Phoxinus phoxinus, Rutilus rutilus, Tinca tinca, Cyprinus carpio. The last two species were only found upstream to the eutrophic pond. Downstream of the eutrophic pond an eel (Anguilla anguilla) was seen once. At the Lake Constance site Noemacheilus barbatulus and juvenile burbot (Lota lota) were found regularly.

\section{Food selection experiments}

Austropotamobius torrentium fed on all food items offered (Figure 5). Even some fish (3 of 10 sticklebacks were caught within 7 days), flatworms and leeches (not quantified) were consumed by crayfish. The total food amount consumed by the crayfish in June (at $14^{\circ} \mathrm{C}$ ) was higher than in May $\left(\right.$ at $7^{\circ} \mathrm{C}$ ) (Figure 5). In May the dry weight of their food on average amounted to $10.4 \pm 8.6 \mathrm{mg}$ (mean $\pm \mathrm{SD}$ ) per animal and day. In June they consumed $56.2 \pm 33.1 \mathrm{mg}$ (mean $\pm \mathrm{SD}$ ) per day. Among the plant material crayfish showed a preference for limnephilid cases and for dead leaves (Figure $5,14^{\circ} \mathrm{C}$ ). The bivalve Dreissena polymorpha was the preferred animal food source followed by gastropods. Insect larvae and amphipods were also consumed at $14^{\circ} \mathrm{C}$. At lower temperatures Gammarus fossarum constituted the dominant source of animal food of stone crayfish (Figure $5,7^{\circ} \mathrm{C}$ ).

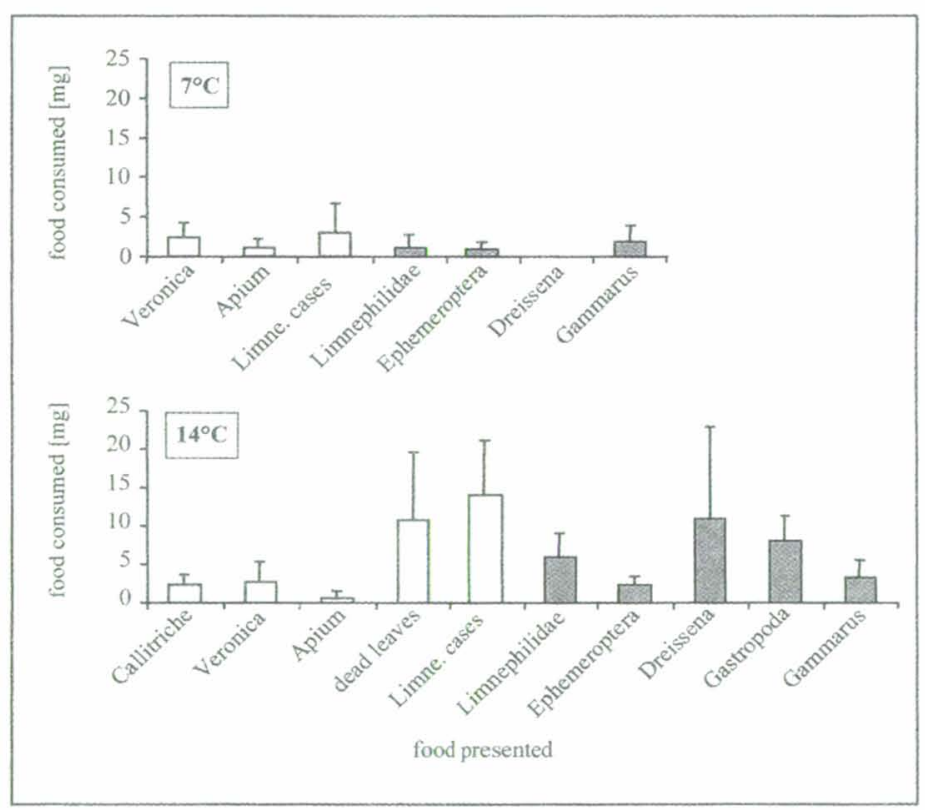

Figure 5

The results of the food preference experiments. Average dry weight and standard deviation of food consumed by individual Austropotamobius torrentium are given. Five crayfish were tested at $7^{\circ} \mathrm{C}$ (upper graph) and 17 crayfish were tested at $14^{\circ} \mathrm{C}$ (lower graph). Open bars indicate vegetable food, gray bars denote to animal food.

\section{Figure 5}

Les résultats des expériences concernant la sélection de la nourriture. Poids sec moyen et déviation standard de la nourriture consommée individuellement par des Austropotamobius torrentium sont indiqués. Cinq écrevisses ont été étudiées à $7^{\circ} \mathrm{C}$ (graphe supérieur) et 17 écrevisses ont été étudiées à $14^{\circ} \mathrm{C}$ (graphe inférieur). Les colonnes ouvertes sont relatives à la nourriture végétale, les colonnes grises indiquent la nourriture animale. 


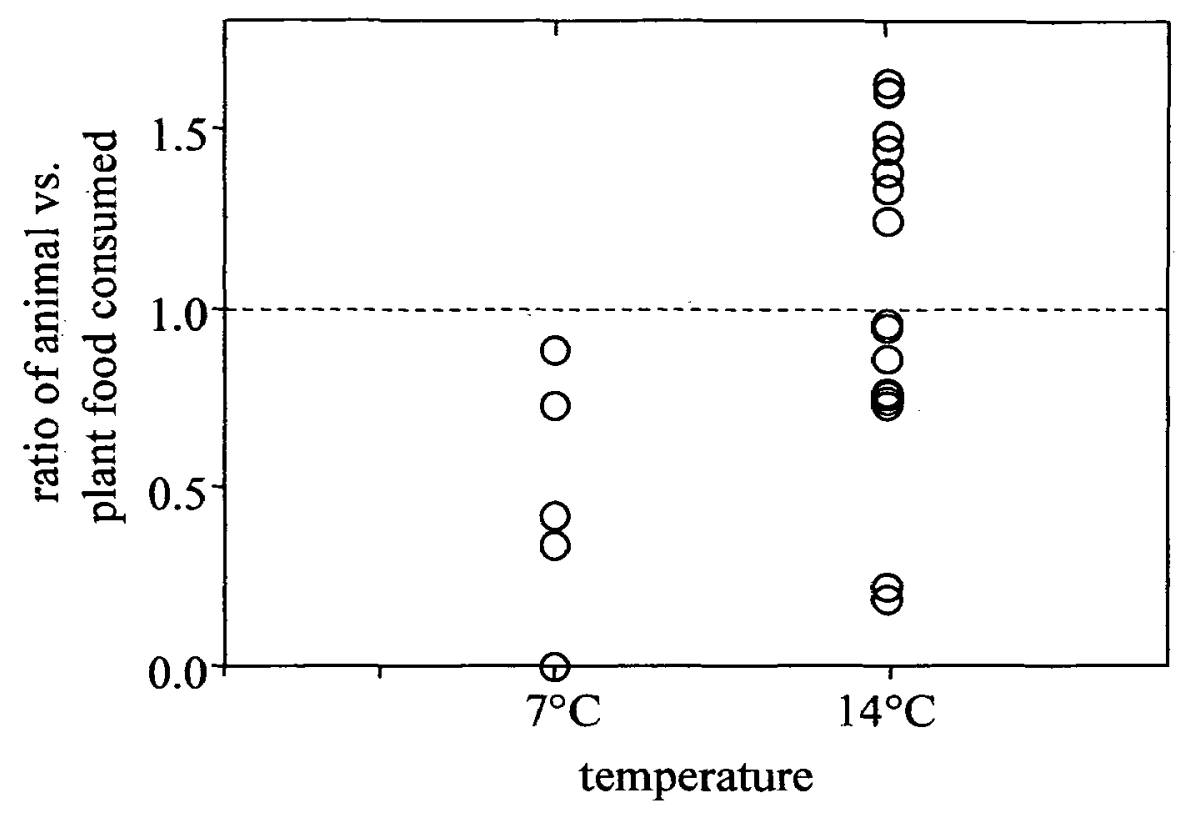

Figure 6

Effect of temperature on the ratio of animal to plant food (dry weight) that was consumed by individuals of Austropotamobius torrentium. See text for further explanations. The ratio increased significantly with increasing temperature (Three-Way Anova, $\mathrm{p}<0.05$ ).

\section{Figure 6}

Effet de la température sur le ratio de la nourriture animale et végétale (poids sec) consommée en moyenne par des individus d'Austropotamobius torrentium. Voir le texte pour des explications plus détaillées. Le ratio montre une augmentation significative quand la température monte (test Three-Way Anova, $p<0,05)$.

The proportion of animals in the diet of Austropotamobius torrentium in spring was lower than in summer (three-way Anova : $F=6.2, p=0.02$; Figure 6). The ratio of animals to plant weight consumed had a mean of $0.43 \pm 0.20$ (SE) at $7^{\circ} \mathrm{C}$ and $1.03 \pm 0.12$ (SE) at $14^{\circ} \mathrm{C}$. Other factors (body size, original habitat) tested in the three-way Anova had no significant influence on the proportion of animals in the diet.

\section{DISCUSSION}

At the first view the habitats occupied by Austropotamobius torrentium in the Lake Constance region show strong differences. Habitat types range from small forest brooks with very low flow discharge (study site 1) to a site in Lake Constance with very high flow discharge. The presence of stone crayfish in Lake Constance is remarkable since their occurrence is usually restricted to small brooks (LAURENT, 1988 ; BOHL, 1999). The location in Lake Constance inhabited by Austropotamobius torrentium was the outflow of the river Rhine characterized by high flow speeds. It seems that $A$. torrentium needs a minimum flow speed for colonization of a habitat. In our study the maximum flow velocities at crayfish body height ranged from $2 \mathrm{~cm} / \mathrm{s}$ to $26 \mathrm{~cm} / \mathrm{s}$. In the brooks, areas of much lower flow speed existed (e.g. in the downstream shadow of roots, driftwood, big stones). The distribution of flow velocities in the brook habitats were found to be very heterogeneous. For example, at two locations separated by a distance of only $10 \mathrm{~cm}$ we measured velocities from $1 \mathrm{~cm} / \mathrm{s}$ to $30 \mathrm{~cm} / \mathrm{s}$ respectively. BOHL (1989b) estimated an upper velocity limit of $30 \mathrm{~cm} / \mathrm{s}$ for the occurrence of Austropotamobius torrentium in Bavaria, Germany. 
He suggests that high flow speeds increase the downstream drift of juvenile crayfish and cause movements of stones that destroy crayfish shelters and may even damage the animals themselves. Together these factors may limit invasion of stone crayfish into areas with very strong currents (BOHL, 1989b). He points out that heterogeneous flow conditions are typical for stone crayfish habitats.

Structural richness is another factor characterizing the stone crayfish habitat. All study sites examined in this study contained potential shelter area like big stones, driftwood or roots of trees. We found an increase in crayfish abundance with increasing availability of shelter area (see Table I ; BREITHAUPT and RENZ, unpublished data). In addition, juvenile and adult crayfish seem to have different habitat demands. Small crayfish were predominantly found on gravel or pebble substrate while larger specimen were also found on sandy substrate (BREITHAUPT and RENZ, unpublished data) suggesting a different shelter use of the two size classes. SMITH et al. (1996) showed a strong correlation between crayfish population density and structural richness at the bank of rivers inhabited by Austropotamobius pallipes. BLESS (1981) emphasized the correlation between species diversity and structural richness of a brook biotope. All sites examined in our study had a Saprobial index of about 2 indicating a good species diversity in all habitats. Thus, structural richness secures hiding-places for several size classes of crayfish. It also provides ecological niches for a diverse community of benthic organisms which can serve as potential food sources for the crayfish (BERG et al., 1989).

The chemical parameters showed great differences between the lake habitat and the brook habitats (see Table I). Calcium concentration and conductivity are both much lower in the lake $\left(\mathrm{Ca}^{2+}: 50 \mathrm{mg} / \mathrm{l}\right.$; conductivity : $\left.300 \mu \mathrm{S} / \mathrm{cm}\right)$ than in the brooks $\left(\mathrm{Ca}^{2+}\right.$ : $110 \mathrm{mg} / \mathrm{l}$; conductivity : $\left.670 \mu \mathrm{S} / \mathrm{cm}\right)$. However, both $\mathrm{Ca}^{2+}$ concentration and conductivity as well as $\mathrm{pH}$ and oxygen were well within the range of values found by $\mathrm{BOHL}$ $(1989 \mathrm{~b})$ in the Bavarian habitats of Austropotamobius torrentium. Only the maximal temperature in Lake Constance $\left(21.6^{\circ} \mathrm{C}\right)$ exceeded those measured in stone crayfish habitats in Bavaria $\left(20^{\circ} \mathrm{C}, \mathrm{BOHL}, 1989 \mathrm{~b}\right)$. The Saprobial index of about 2 indicated a moderate pollution both in the lake and in the brooks. Downstream of the eutrophic pond the Saprobial index was raised to 2.5 (critically polluted). Stone crayfish did not invade the eutrophic pond. This pond had a high organic load and a high phytoplankton production in summer. The daytime temperature in the summer is about $25^{\circ} \mathrm{C}$ from June to August (KIECHLE et al., 1999). This is far above the optimal temperature range of stone crayfish $\left(14^{\circ} \mathrm{C}\right.$ to $18^{\circ} \mathrm{C}$ ) and still above the upper tolerable temperature limit of $23^{\circ} \mathrm{C}$ (HAGER, 1996). Due to the high phytoplankton concentration in summer the oxygen saturation in the pond is high (occasionally higher than $300 \%$ ) in the daytime and low at night. The floor of the lake was covered by a 30 to $80 \mathrm{~cm}$ thick layer of mud. Thus multiple factors made the lake habitat unsuitable for a stone crayfish invasion. These factors also inhibited a downstream spread of the crayfish population of study site 2 .

Another threat for the stone crayfish is imposed by obstructions of small running waters (DEHUS, 1997). In our study the channelling of the brooks through pipes below the street inhibited upstream invasion of potentially good crayfish habitats. At the downstream side of the street these pipes opened at a height of $1 \mathrm{~m}$ above water level, making it impossible for the crayfish to enter them. Obstructions like these pipes act as barriers for the spread of crayfish. They constitute a major threat for the stone crayfish since they can subdivide and isolate populations. The isolated population sites due to the barriers cannot be resettled in the case of damage of the native population (BOHL, 1999) and thus brook obstructions may eventually lead to extinction of stone crayfish at these sites. In order to prevent such population losses in the future the obstructions should be redesigned to allow invasion of crayfish. The tunnel crossing below the street at study site 2 is inhabited by 
crayfish. A rough stony bottom level with at least the downstream brook section diminishes the obstructing effect of the street underpass.

The food selection experiments revealed that stone crayfish are food generalists. They fed on all food items offered. They even showed predatory success with regard to swimming prey (amphipods, maytly larvae, fish, leeches). The specialisation of the sensory organs of crayfish to nocturnal activity may explain the predatory success with regard to swimming animals. BREITHAUPT et al. (1995) found that blindfolded crayfish (Procambarus clarki) can orientate towards and catch small swimming fish using mechanosensory cues. HESSEN and SKURDAL (1986) found amphipods in the stomachs of Astacus astacus. Other crayfish species (Pacifastacus leniusculus, Orconectes virilis) failed to catch swimming macroinvertebrates (HANSON et al., 1990, NYSTRÖM et al., 1996). In some brook habitats (e.g. site 1 of this study) amphipods constitute $90 \%$ of the total biomass and thus may be the best food resource available. While in some crayfish species snails are the main food source (HANSON et al., 1990) in our food selection experiments their contribution to the diet of Austropotamobius torrentium was much lower. A reason for this mismatch could be that the calcium concentration in the brook habitats was very high, so that crayfish did not need snails as additional calcium source.

At spring conditions $\left(7^{\circ} \mathrm{C}\right)$ the stone crayfish mainly fed on plants while in summer the diet was balanced with regard to animal and plant food. Similarly, HESSEN and SKURDAL (1986) found in Astacus astacus that the proportion of animal food is higher in autumn than in spring. The high proportion of plants in the diet of $A$. torrentium early in the year could reflect a deficit of plant nutrients (e.g. minerals, proteins) in crayfish after winter. In summer the stone crayfish also consumed dead leaves (Figure 5). In Pacifastacus leniusculus $68 \%$ of the stomach content could be fallen leaves (GODDARD, 1988). In contrast to these species ANWAND and VALENTIN (1996) did not find leaves in the stomachs of Orconectes limosus.

\section{CONCLUSION}

In Southern Germany the stone crayfish Austropotamobius torrentium may be the most abundant of the European craytish species but due to its small size and structural richness of its habitat is easily overlooked. It needs a habitat with flowing water but is not restricted to small brooks or creeks. It is an opportunistic feeder consuming almost all plants and animals found in its habitat. Due to the little overlap with the habitats of introduced American species the stone crayfish is less threatened by the crayfish plague than the other European species. Channellings and other obstructions of its habitat, however, impose a major threat to the stone crayfish leading to isolation and eventually to loss of populations. Conservation of the natural habitat of Austropotamobius torrentium, brooks and rivers with structural richness and hard bottom material (sand, gravel, stones), and modification of existing obstructions in their habitat (e.g. by avoiding water falls and smooth slippery surfaces that restrain the spread of crayfish) are needed to protect this species in the future.

\section{ACKNOWLEDGEMENTS}

We are very grateful to Myriam Schmid, Kirsten Pohlmann, Marlies Krüger, Michael von der Wall and Stefan Höger for repeatedly helping us to collect and mark crayfish at night ; to Kirsten Pohlmann and two anonymous referees for valuable comments on a previous version of the manuscript ; to Gabi Breithaupt and Edith Fix for helping to translate the text ; to Professor Axel Meyer for supporting the study. The reseach was supported by the Deutsche Forschungsgemeinschaft ( $\mathrm{Br} 1321 / 3-1)$. 


\section{REFERENCES}

ANWAND K., VALENTIN M., 1996. Über die Ernährungsbiologie von Orconectes limosus (Raf.), Crustacea. Limnologica, 26 (1), 83-91.

ATTEN D., 1988. La répartition des écrevisses au Grand-Duché de Luxembourg. L'Astaciculteur de France, 15, 1-5.

BERG R., BLANK S., STRUBELT T., 1989. Fische in Baden-Württemberg. Ministerium für Ländlichen Raum, Ernährung, Landwirtschaft und Forsten BW, Stuttgart, 158 p.

BLESS R., 1981. Untersuchungen zum Einfluß von gewässerbaulichen Maßnahmen auf die Fischfauna in Mittelgebirgsbächen. Natur und Landschaft 5, 243-252.

BOHL E., 1989a. Comparative studies on crayfish brooks in Bavaria (Astacus astacus L., Austropotamobius torrentium Schr.). Freshwater Crayfish, 7, 287-294.

BOHL E., 1989b. Ökologische Untersuchungen zur Entwicklung von Zielvorstellungen des Gewässerschutzes. Untersuchungen an Flußkrebsbeständen. Schriftenreihe der Bayerischen Landesanstalt für Wasserforschung, München, $237 \mathrm{p}$.

BOHL E., 1999. Crayfish stock situation in Bavaria - attributes, threats and chances. Freshwater crayfish (in press).

BREITHAUPT T., SCHMITZ B., TAUTZ J., 1995. Hydrodynamic orientation of crayfish (Procambarus clarkii) to swimming fish prey. J. Comp. Physiol. A, 177, 481-491.

DEHUS P., 1997. Flußkrebse in Baden-Württemberg, Gefährdung und Schutz. Information der Fischereiforschungsstelle des Landes Baden-Württemberg, 2. Auflage, Staatl. Lehr - und Versuchsanstalt Aulendorf, $26 \mathrm{p}$.

DYCK S., PESCHKE G., 1989. Grundlagen der Hydrologie. Wilhelm Ernst und Sohn, Berlin, $408 \mathrm{p}$.

GODDARD J.S., 1988. Food and feeding. In HOLDICH D.M., LOWERY R.S. (eds.), Freshwater Crayfish, 145-166, University Press, Cambridge.

HAGER J., 1996. Edelkrebse : Biologie, Zucht, Bewirtschaftung. Leopold Stocker Verlag, Graz, 128 p.

HANSON J.M., CHAMBERS P.A., PREPAS E.E., 1990. Selective foraging by the crayfish Orconectes virilis and its impact on macroinvertebrates. Freshwater Biology, 24, 69-80.

HESSEN D.O., SKURDAL J., 1986. Analysis of food utilised by the crayfish Astacus astacus in lake Steinsfjorden, S.E. Norway. Freshwater Crayfish, 6, 187-193.

HOGGER J.B., 1988. Ecology, population biology and behavior. In HOLDICH D.M. and LOWERY R.S. (eds.), Freshwater Crayfish, 114-144, University Press, Cambridge.

JOLLY G.M., 1965. Explicit estimates from capture-recapture data with both death and immigration-stochastic model. Biometrika, 52, 225-247.

KIECHLE J., MAIER K.J., SCHORK M., 1999. NSG Mühlhaldenweiher : Limnologischökologische Untersuchungen, Vegetation, Pflege und Entwicklung. Gutachten erstellt im Auftrag der Bezirksstelle für Naturschutz und Landschaftspflege Freiburg (in press).

LAURENT P.J., 1988. Austropotamobius pallipes and A. torrentium, with observations on their interactions with other species in Europe. In HOLDICH D.M. and LOWERY R.S. (eds.), Freshwater Crayfish, 341-364, University Press, Cambridge.

MACHINO Y., 1996. Nouveau site de l'écrevisse de torrent (Austropotamobius torrentium (Schrank, 1803)) en France. L'Asticiculteur de France, 48, 2-3.

MEYER, D., 1987. Makroskopisch-biologische Feldmethoden zur Wassergütebeurteilung von Fließgewässern. BUND Schriftenreihe, Hannover, $156 \mathrm{p}$. 
MEYER, E., 1989. The relationship between body length parameters and dry mass in running water invertebrates. Arch. Hydrobiol., 117, 191-203.

NAGEL P., 1989. Bildbestimmungsschlüssel der Saprobien. Gustav Fischer Verlag, Stuttgart, $183 \mathrm{p}$.

NORMENAUSSCHUB WASSERWESEN (NAW) im DIN (Deutsches Institut für Normung) e.V., 1987. Biologisch-ökologische Gewässeruntersuchung (Gruppe $M$ ) ; DIN 38410, Teil 2., Berlin, $18 p$.

NYSTRÖM P., BRÖNMARK C., GRANELI W., 1996. Patterns in benthic food webs : A role for omnivorous crayfish ? Freshwater Biology, 36, 631-646.

SEBER G.A., 1965. A note on the multiple-recapture census. Biometrika, 52, 249-259.

SMITH R.G.T., LEANER M.A., SLATER F.M., FOSTER J., 1996. Habitat features important for the conservation of the native craytish Austropotamobius pallipes in Britain. Biological Conservation, 75, 239-246.

TROSCHEL H.J., DEHUS P., 1993. Distribution of crayfish species in the Federal Republic of Germany, with special reference to Austropotamobius pallipes. Freshwater Crayfish, 9, 390-398. 